\title{
Assessment of community awareness and risk perceptions of zoonotic causes of abortion in cattle at three selected livestock-wildlife interface areas of Zimbabwe
}

\author{
M. NDENGU ${ }^{1,2 *}$, M. DE GARINE-WICHATITSKY ${ }^{2,3,4}$, D. M. PFUKENYI ${ }^{1,2}$, \\ M. TIVAPASI ${ }^{1,2}$, B. MUKAMURI ${ }^{2,5}$ AND G. MATOPE 2,6 \\ ${ }^{1}$ Department of Clinical Veterinary Studies, Faculty of Veterinary Science, University of Zimbabwe, P.O. Box \\ MP 167, Mount Pleasant, Harare, Zimbabwe \\ ${ }^{2}$ Research Platform Production and Conservation in Partnership, P. O. Box 1378, Harare, Zimbabwe \\ ${ }^{3}$ Department of Biological Sciences, Faculty of Science, University of Zimbabwe, P.O. Box MP 167, Mount \\ Pleasant, Harare, Zimbabwe \\ ${ }^{4}$ UR AGIRs, Cirad, Campus International de Baillarguet, 34398 Montpellier, France \\ ${ }^{5}$ Centre for Applied Social Sciences, University of Zimbabwe, P.O. Box MP 167, Mount Pleasant, Harare, \\ Zimbabwe \\ ${ }^{6}$ Department of Paraclinical Veterinary Studies, Faculty of Veterinary Science, University of Zimbabwe, P.O. \\ Box MP 167, Mount Pleasant, Harare, Zimbabwe
}

Received 17 February 2016; Final revision 15 November 2016; Accepted 24 December 2016; first published online 6 February 2017

\section{SUMMARY}

A study was conducted to assess the awareness of cattle abortions due to brucellosis, Rift Valley fever (RVF) and leptospirosis, and to compare frequencies of reported abortions in communities living at the periphery of the Great Limpopo Transfrontier Conservation Area in southeastern Zimbabwe. Three study sites were selected based on the type of livestock-wildlife interface: porous livestock-wildlife interface (unrestricted); non-porous livestock-wildlife interface (restricted by fencing); and livestock-wildlife non-interface (totally absent or control). Respondents randomly selected from a list of potential cattle farmers $(N=379)$ distributed at porous $(40 \cdot 1 \%)$, non-interface $(35 \cdot 5 \%)$ and non-porous $(26 \cdot 4 \%)$, were interviewed using a combined close- and open-ended questionnaire. Focus group discussions were conducted with 10-12 members of each community. More abortions in the last 5 years were reported from the porous interface $(52 \%)$ and a significantly higher per cent of respondents from the porous interface $(P<0.05)$ perceived wildlife as playing a role in livestock abortions compared with the other interface types. The odds of reporting abortions in cattle were higher in large herd sizes (odds ratio $(\mathrm{OR})=2 \cdot 6 ; 95 \%$ confidence interval $(\mathrm{CI}) 1 \cdot 5-4 \cdot 3)$, porous $(\mathrm{OR}=1 \cdot 9 ; 95 \% \mathrm{CI} 1 \cdot 0-3 \cdot 5)$ and non-porous interface ( $\mathrm{OR}=2 \cdot 2 ; 95 \% \mathrm{CI} 1 \cdot 1-4 \cdot 3)$ compared with livestock-wildlife noninterface areas. About $21.6 \%$ of the respondents knew brucellosis as a cause of abortion, compared with RVF $(9 \cdot 8 \%)$ and leptospirosis $(3 \cdot 7 \%)$. These results explain to some extent, the existence of human/wildlife conflict in the studied livestock-wildlife interface areas of Zimbabwe, which militates against biodiversity conservation efforts. The low awareness of zoonoses means the public is at risk of contracting some of these infections. Thus, further studies should focus on livestock-wildlife interface areas to assess if the increased rates of abortions reported in cattle may be due to exposure to wildlife or other factors. The government of Zimbabwe needs to

\footnotetext{
* Author for correspondence: Dr. M. Ndengu, Department of Clinical Veterinary Studies, Faculty of Veterinary Science, University of Zimbabwe, P.O. Box MP 167, Mount Pleasant, Harare, Zimbabwe.

(Email: masimbandengu@gmail.com, mndengu@vet.uz.ac.zw)
} 
launch educational programmes on public health awareness in these remote areas at the periphery of transfrontier conservation areas where livestock-wildlife interface exists to help mitigate the morbidity and mortality of people from some of the known zoonotic diseases.

Key words: Brucellosis, Rift Valley Fever, Leptospirosis, livestock-wildlife interface.

\section{INTRODUCTION}

In the marginal rural areas of Zimbabwe, smallholder mixed crop-livestock farming systems predominate, and cattle play key roles in the livelihoods of people in these systems. They utilise resources (crop residues and fallow land) that would otherwise go to waste and are important sources of meat and milk. They also provide draught power, manure for fertiliser and are often used in traditional practices such as 'lobola' (i.e. dowry). Although markets are often restricted, cash generated by the sale of these cattle can be used to purchase farm inputs such as seed, fertiliser and implements, thus improving income and livelihoods. Cattle are also an important social status symbol in these communities as they may act as a source of cash reserves [1]. These cattle-related benefits can only be sustainable if causes of reproductive problems including abortions are identified and controlled.

Brucellosis, leptospirosis and Rift Valley fever (RVF) are important zoonotic causes of abortion in ruminants that also affect humans, with various clinical manifestations and sometimes causing death. The three diseases have different modes of transmission amongst animals with brucellosis being shed in products of abortion. It is therefore acquired through ingestion of contaminated pastures and water. Leptospirosis, on the other hand, is spread mainly through water contaminated by urine voided from infected animal reservoirs that include rodents, dogs or wildlife, while RVF is mainly arthropod-borne.

The livestock-wildlife interface is defined as a direct physical sharing of the same space at the same time or indirect contact through soil, forage and water with which another animal had recently been in contact and left bodily secretions [2]. Interactions at the livestock-wildlife interface have been shown to influence disease dynamics because of the sharing of grazing land and water between domestic and wild animals $[2,3]$. In Zimbabwe, the exposure to some of the infectious agents has been demonstrated in cattle from both the non-interface areas where livestock are not in contact with wildlife [4-6] and livestock-wildlife interface areas [7, 8]. For instance, brucellosis has been shown to exist in several wildlife species such as the buffalo (Syncerus caffer), zebra (Equus burchelli), giraffe (Giraffa camelopardalis) and impala (Aepyceros melampus) [9]. Recent studies in the livestock-wildlife interface areas documented brucellosis seroprevalence of $9.9 \%$ in cattle [7]. In the unfenced livestock-wildlife (porous) interface area of Malipati, RVF was detected in both buffaloes $(5 \cdot 3 \%)$ and in cattle $(18 \cdot 3 \%$ ), while in fenced livestock-wildlife (nonporous) interface area of Chizvirizvi and non-interface area of Chikombedzi, the seroprevalence in cattle was $8 \cdot 5 \%$ and $7 \cdot 7 \%$, respectively [8]. There are no current surveillance data for leptospirosis in the country. However, previous studies documented cattle leptospirosis seroprevalence of $34 \%$ in other parts of the country [10]. Wildlife is often perceived as a reservoir of infection for livestock and diseases such as foot and mouth disease (FMD) [11], rabies, African swine fever and avian influenza [12] are known to originate from wildlife. This, coupled with predation and crop destruction, has often led to conflicts between humans and wildlife, a feature that is particularly prominent at human-livestock-wildlife interface areas [13]. The establishment of regional transfrontier wildlife conservation areas such as the Great Limpopo Transfrontier Conservation Area (GLTFCA) together with the disruption of fences erected as part of the FMD control measures has resulted in increased livestock-wildlife contact and heightening the tension between humans and wildlife [14].

The aims of this study, which is part of a broader investigation, were to:

(a) assess the awareness of infectious abortion in cattle due to three zoonotic infections (Brucellosis, RVF and Leptospirosis);

(b) investigate the risky practices and preventive measures for ruminants and human infections; and

(c) compare the frequencies of reporting abortion in cattle in the communities selected from the Zimbabwean side of the GLTFCA representing three distinct areas of unrestricted (porous), restricted by fencing (non-porous) livestock-wildlife 
interface and non-interface (absent) areas with a view to mitigate against human/wildlife conflict and therefore promote wildlife biodiversity.

\section{METHODS}

\section{Study area}

The GLTFCA was created in 2002 to co-manage as one ecological unit, the several national parks, communal land and private land located in Mozambique, South Africa and Zimbabwe [15]. In Zimbabwe, Gonarezhou National Park (GNP), a semi-arid ecosystem, and the communal land on its periphery are part of the GLTFCA. The study area is located in the SEL (South East Lowveld) of Zimbabwe, which lies in agro-ecological Natural Region $\mathrm{V}$ and is characterised by low elevations, high temperatures, and low and erratic rainfall (on average $<600 \mathrm{~mm} /$ year) [16]. The study sites (Fig. 1) were selected based on the interface type: the livestock-wildlife interface where domestic and wild animals interact and the non-interface where domestic animals are not in contact with wildlife. The livestock-wildlife interface was of two types: a porous interface representing an unrestricted livestockwildlife contact and a non-porous interface representing a restricted livestock-wildlife interaction by fencing. The cattle population in all the three study sites (porous, non-porous and non-interface) are mainly crosses of the indigenous Mashona and Nguni breeds. These study sites are further described in detail below.

\section{Study sites and interface types}

Porous livestock-wildlife interface. Malipati village $\left(22^{\circ} 04^{\prime} \mathrm{S}, 31^{\circ} 25^{\prime} \mathrm{E}\right)$ is located at the southern border of GNP on Sengwe communal lands [17]. The park boundary lies a few hundred metres from the village. A veterinary fence was erected in 1985 along the park border to prohibit cattle/buffalo contacts, mainly to prevent the transmission of the FMD virus. However, the fence is mostly ineffective at present because it has been damaged extensively by wildlife and people allowing free movement of livestock into the park as well as wildlife accessing human settlements. Similarly, cattle in this area, which is estimated at about 1528 according to the Zimbabwe Department of Veterinary Services (ZDVS) 2015 annual report, are often grazed in the national park in times of grazing shortages. There is also co-sharing of water sources between cattle and wildlife. Wildlife also approach communal areas for predation of livestock and access to crops. It is therefore assumed that there is significant contact between humans, livestock including cattle and wildlife at this type of interface.

Non-porous livestock-wildlife interface. Chizvirizvi village $\left(20^{\circ} 59^{\prime} \mathrm{S}, 32^{\circ} 01^{\prime} \mathrm{E}\right)$ is located on the periphery of the Malilangwe conservancy, $405 \mathrm{~km}^{2}$ of private land dedicated to wildlife tourism lying next to the northern boundary of the GNP that is surrounded by a well-maintained game fence. This fence is regularly maintained by the conservancy staff and can be assumed to be largely ungulate-proof and hinders direct contact between wildlife on one side of the fence, and humans and livestock on the other. The conservancy hosts the full range of African wild ungulates occurring in the area. Large ungulates such as buffalo have never been observed outside the fence in the surrounding communal land area. On the other side of the fence, the Chizvirizvi village hosts livestock, which are mainly cattle, goats and sheep. The fence creates a physically defined interface, separating wildlife and cattle whose population is estimated at 1470 according to ZDVS 2015 records.

Livestock-wildlife non-interface. Chomupani communal land $\left(21^{\circ} 40^{\prime} \mathrm{S}, 31^{\circ} 19^{\prime} \mathrm{E}\right)$ is located at least $15 \mathrm{~km}$ from the northwestern boundary of GNP. Wild ungulates are reportedly absent in the Chomupani area and this site was considered to be a control site with no wildlife/livestock interactions as it was far away from the national park. According to the ZDVS 2015 records, the cattle population in this area is estimated at 2300 .

\section{Study design}

A cross-sectional study was designed targeting communities and individual households in the three study sites of Chomupani, Chizvirizvi and Malipati. Communal cattle dip tanks were used as sampling frames for the communities in each of the selected study areas. In Zimbabwe, animal health regulations compel all cattle owners in rural areas to dip their cattle weekly during the rainy season and fortnightly during the dry season for control of ticks and tick-borne diseases [18]. For this reason, the Government, through the Department of Livestock and Veterinary Services, has constructed communal dip tanks (plunge 


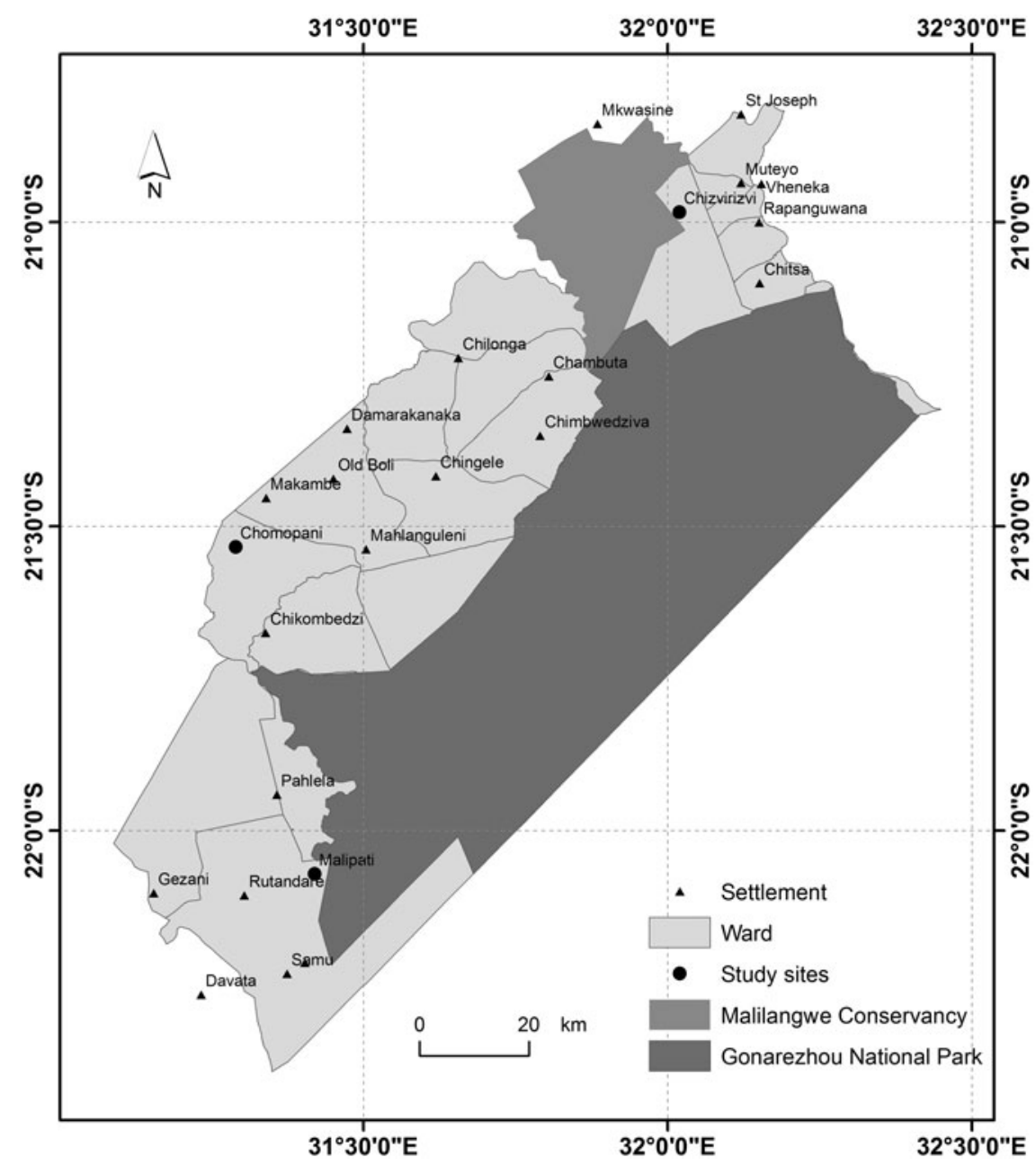

Fig. 1. Map of the south-eastern Lowveld of Zimbabwe showing the GNP and the adjacent Malilangwe Conservancy. Note the three study sites represented by big black dots.

dip tanks) in all rural animal health centres, which are accessible by all farmers in the rural communities. Since a list of names of all farmers who dip their cattle or those who are likely to use (if without cattle) any of the dip tanks, is kept with the local veterinary offices based in each of the areas, this was considered representative of the communities. The total number of farmers listed from the three selected dip tanks was 3078 (Malipati $=1267$, Chomupani $=993$, Chizvirizviri $=$ 818). A minimum targeted sample size of farmers from each dip tank was $10 \%$ and a total of 379 farmers was selected (Malipati $=152, \quad$ Chomupani $=127$, Chizvirizviri $=100$ ). The farmers from each area were identified by their names written on small cards and farmers to be interviewed were then chosen randomly from a bowl. Thus, the farmers were selected with no conditional inclusion criteria and no previous knowledge of livestock ownership.

\section{Data collection}

A pre-tested structured questionnaire was designed and administered at each selected household in the three study sites. The questionnaire consisted of both close- and open-ended questions. Field pre-testing of the questionnaire was conducted by the principal researcher in another area, which was not included in the final study, where a total of 15 randomly farmers were interviewed. The easiness and lack of clarity of some questions was noted and later revised to improve accuracy of the information collected. The questionnaires were administered to the head of the household by the principal researcher (and a trained assistant) and the interviews lasted approximately $20 \mathrm{~min}$ each. Where the household head was not present, the researchers would move to the next household. The questionnaire was administered in English, 
and where necessary, with the help of a trained assistant who is knowledgeable about the vernacular languages in the areas, the questions were translated into Shangani or Shona languages for easier communication. The questionnaire was intended to characterise households with respect to livestock husbandry practices, livestock ownership patterns, livestock health-related issues, including knowledge of causes of abortion in cattle, sheep and goats and possible transmission modes of these diseases. In addition, it also addressed issues to do with knowledge of zoonoses particularly brucellosis, leptospirosis and RVF, history of human infection with those zoonoses and methods employed to treat and prevent such infections in both livestock and humans. Respondents were also asked on the possible role of wildlife in the causation of abortion in cattle. Several factors that influence disease morbidity in both humans and livestock were investigated by the questionnaire. Amongst them were frequency of human-livestockwildlife contact, water sources for human, livestock and wildlife, meat and milk consumption patterns and preparation of food of animal origin prior to consumption. The disposal of abortion products was also investigated. Key informant interviews and focus group discussions (FSD) were conducted after initial assessment of the household questionnaires. One group of 10-12 members [19] of the community per study site representing both males and females in equal proportions, participated in FSD. The participants were selected on the criteria that they were more knowledgeable of the topics and study area, had similar socio-characteristics and were comfortable to discuss issues among themselves and with the facilitator [19]. Key informants from the Department of Livestock and Veterinary Services assisted in selecting the participants. Similarly at each study site, The Department of Livestock and Veterinary Services staff, resident Parks and Wildlife Management staff and local ministry of health staff were interviewed as key informants. Each category of the key informants was interviewed separately. Both the key informant interviews and FSD were conducted as a means of verifying some of the respondents' answers to the questionnaire (triangulation of information, consensus information). Data generated during key informants' interviews and FSD were collected through audiotapes and notes taken by the facilitator and the principal investigator.

\section{Statistical analysis}

The data were summarised, edited, compiled, coded and stored in Microsoft Excel spread sheet and transferred to SPSS ${ }^{\circledR}$ Version 21 (IBM Corp, 2012) for statistical analysis. Descriptive and analytic statistics for most variables were computed using software SPSS ${ }^{\circledR}$ Version 21(IBM Corp, 2012). Association between history of abortion and categorical variables was tested using the Chi-square $\left(\chi^{2}\right)$ test. To establish associations between the reported abortions and the explanatory variables, a subset of the data for respondents who have owned cattle among other species $(n=254)$ in the last 5 years and having complete records for the investigated variables were further analysed using multivariable logistic regression analyses performed in STATA/SE version 10.0 (Stata, College Station, Texas, USA). Univariable analyses were used to assess the strength of association between the reported abortions $(0=$ no; $1=$ yes $)$ as the dependent variable and the explanatory variables believed to be influencing the reported abortions; area of origin $(0=$ noninterface; $1=$ non-porous interface; $2=$ porous interface), contact with wildlife $(0=$ no; $1=$ yes $)$, keeping cattle together with goats and/or sheep $(0=$ no; $1=$ yes), and the total number of cattle kept per household $(0=\leqslant 8 ; 1=>8)$. Other husbandry practices were not explored. The explanatory variables were screened using a two-sided Fisher's exact $\chi^{2}$ test. Only variables with $P$-values $<0 \cdot 25$ (area of origin and the total number of cattle kept per household) with counts $\geqslant 5$ in each cell and having no missing values were presented to the multivariable logistic regression model.

The multivariable logistic regression model was built using the reported abortions $(0=$ no; $1=$ yes $)$ as the dependent variable and the explanatory variables identified to have $P$-values $<0.25$ in univariate analyses. The model was manually constructed using a backward selection procedure and the statistical contribution of the explanatory variables to the model was tested using the likelihood ratio test [20]. The logistic regression model was assessed for goodness-of-fit using the Hosmer-Lemeshow test and the predictive ability was determined using the receiver operating characteristic (ROC) curve.

Descriptive analysis was used to analyse the key informants' interview and FSD data. Briefly, this involved a description of the main points raised by interviewees. 
Table 1. Number of rural livestock farmers interviewed according to interface category and sex

\begin{tabular}{llllll}
\hline \hline & & \multicolumn{2}{l}{ Sex } & & \\
\cline { 3 - 4 } Interface category* & Site & Male & Female & Sex not indicated & Total (\%) \\
\hline Porous & Malipati & 79 & 73 & 0 & $152(40 \cdot 1)$ \\
Non-interface & Chomupani & 94 & 33 & 0 & $127(33 \cdot 5)$ \\
Non-porous & Chizvirizviri & 65 & 26 & 9 & $100(26 \cdot 4)$ \\
Total $(\%)$ & & $238(62 \cdot 8)$ & $132(34 \cdot 8)$ & $9(2 \cdot 4)$ & 379 \\
\hline \hline
\end{tabular}

* Porous: In this site, fence separating site from park (GNP) extensively damaged; Non-interface: site far away from the boundary of the park (GNP); Non-porous: an intact fence separating site from game park (Malilangwe).

\section{RESULTS}

\section{Socio-economic characteristics of respondents}

A total of 379 participants were interviewed and $40 \cdot 1 \%(152 / 379)$ of them were from a porous interface (Malipati), while 33.5\% (127/379) and 26.4\% (100/ 379) were from Chomupani and Chizvirizvi, respectively (Table 1). About two-thirds of the respondents $(62.8 \%, 238 / 379)$ were males with the majority $(71 \cdot 0 \%, 269 / 379)$ of the participants being above 30 years of age. Over $88 \%(336 / 379)$ of the interviewees had undergone at least primary school education despite $81 \cdot 3 \%(308 / 379)$ of them reporting no specialised training in agriculture, with only $18.7 \%$ (71/379) reported having undergone some short courses training in agriculture. Seventy-seven per cent (292/379) of the respondents' households were male-headed, while about one-fifth (87/379) was female-headed.

\section{Livestock ownership and their management}

The majority $(93.7 \%, 355 / 379)$ of the respondents owned livestock with $99 \cdot 3 \%, 96 \cdot 1 \%$ and $82 \cdot 0 \%$ from Malipati (porous interface), Chomupani (noninterface) and Chizvirizvi (non-porous interface), respectively. Overall, goat ownership was highest $(76 \cdot 3 \%)$, followed by beef cattle $(64 \cdot 6 \%)$ and poultry $(64 \cdot 6 \%)$. Donkey $(38 \cdot 8 \%)$, sheep $(18 \cdot 5 \%)$ and dairy cattle $(13 \cdot 2 \%)$ ownership was low. Another domestic animal owned by the respondents was the dog $(60.7 \%)$ with an overall median size of two dogs. Except for donkey ownership, ownership of other livestock differed significantly $(P<0.05)$ among the studied sites (Table 2). Malipati recorded a significantly $(P<0.01)$ higher ownership of goats, poultry, beef and dairy cattle than the other two sites, while sheep ownership was significantly $(P<0 \cdot 001)$ higher for Chizvirizviri compared with the other two sites
(Table 2). Except for poultry ownership in all sites and goat ownership in Malipati, most (55.6\%-100\%) owned $<10$ animals (Table 2). The overall median size for poultry was 12 and that for beef cattle was 8. Goats and sheep had overall median sizes of 7 and 6 , respectively, while that for dairy cattle and donkeys was $<4$.

Table 3 presents the summary of respondents' responses to issues on husbandry practices, role of wildlife in disease transmission and disease prevention methods. Most respondents indicated that they use the extensive open grazing system utilising natural pastures both during the wet $(96 \cdot 6 \%)$ and dry $(86 \cdot 1 \%)$ seasons. The utilisation of extensive open grazing system varied significantly $(P<0.05)$ during the dry season with Malipati recording the highest percentage. Paddock grazing was reported by only $9 \%$ of the farmers and all were from Chomupani. Slightly over 50\% $(51.7 \%)$ of the farmers indicated that they provide dry season supplementation with Chomupani recording a significantly $(P<0.01)$ higher percentage than the other two sites. Most $(86 \cdot 2 \%)$ of the farmers reported using crop residues for dry season supplementation. During the wet season, dams $(52 \%)$ and rivers $(38.4 \%)$ are the most utilised watering sources for livestock, while wells $(32 \cdot 2 \%)$, rivers $(31 \%)$ and boreholes $(29 \cdot 7 \%)$ are used during the dry season. Generally, the use of different water sources did not vary significantly $(P>0.05)$ among the sites during the dry season, while it varied significantly $(P<0 \cdot 05)$ among the sites during the wet season for dams and rivers. Utilisation of dams was significantly $(P<$ 0.01) higher for Chomupani, while Malipati recorded a significantly $(P<0 \cdot 01)$ higher utilisation of rivers than the other sites during the wet season.

Contact with wildlife at grazing and watering sites was indicated by $41 \cdot 8 \%$ (135/323) with Malipati (porous interface) recording a significantly $(P<0 \cdot 001)$ 
Table 2. Livestock ownership and demographics for the interviewed rural farmers

\begin{tabular}{|c|c|c|c|c|c|c|c|c|c|c|c|c|c|c|c|}
\hline & \multicolumn{5}{|c|}{$\begin{array}{l}\text { Malipati }(n=152) \\
\% \text { Owning* }\end{array}$} & \multicolumn{5}{|c|}{$\begin{array}{l}\text { Chomupani }(n=127) \\
\% \text { Owning* }\end{array}$} & \multicolumn{5}{|c|}{$\begin{array}{l}\text { Chizvirizviri }(n=100) \\
\% \text { Owning* }\end{array}$} \\
\hline & $\begin{array}{l}\text { Total owning } \\
(\%)^{\dagger}\end{array}$ & $<10$ & $10-20$ & $>20$ & $\begin{array}{l}\text { Median } \\
\text { (range) }\end{array}$ & $\begin{array}{l}\text { Total owning } \\
(\%)^{\dagger}\end{array}$ & $<10$ & $10-20$ & $>20$ & $\begin{array}{l}\text { Median } \\
\text { (range) }\end{array}$ & $\begin{array}{l}\text { Total owning } \\
(\%)^{\dagger}\end{array}$ & $<10$ & $10-20$ & $>20$ & $\begin{array}{l}\text { Median } \\
\text { (range) }\end{array}$ \\
\hline Goats & $134(88 \cdot 2)^{\mathrm{a}}$ & $41 \cdot 0$ & $42 \cdot 5$ & $16 \cdot 4$ & $10 \cdot 5(1-110)$ & $95(74 \cdot 8)^{\mathrm{b}}$ & $70 \cdot 5$ & $26 \cdot 3$ & $3 \cdot 2$ & $6(1-50)$ & $60(60 \cdot 0)^{\mathrm{c}}$ & $78 \cdot 3$ & $18 \cdot 3$ & $3 \cdot 3$ & $3(1-30)$ \\
\hline Poultry & $130(85 \cdot 5)^{\mathrm{a}}$ & $30 \cdot 0$ & $51 \cdot 5$ & $18 \cdot 5$ & $13(1-63)$ & $56(44 \cdot 1)^{\mathrm{b}}$ & 37.5 & $50 \cdot 0$ & $12 \cdot 5$ & $11(1-35)$ & $59(59 \cdot 0)^{\mathrm{c}}$ & $33 \cdot 9$ & $52 \cdot 5$ & $13 \cdot 6$ & $10(1-50)$ \\
\hline Beef & $109(71 \cdot 7)^{\mathrm{a}}$ & $64 \cdot 2$ & $29 \cdot 4$ & $6 \cdot 4$ & $7(1-40)$ & $72(56 \cdot 7)^{\mathrm{b}}$ & $55 \cdot 6$ & $34 \cdot 7$ & $9 \cdot 7$ & $8(1-31)$ & $64(64 \cdot 0)^{\mathrm{a}}$ & $59 \cdot 4$ & $32 \cdot 8$ & $7 \cdot 8$ & $8(1-30)$ \\
\hline Donkeys & $59(38 \cdot 8)^{\mathrm{a}}$ & $98 \cdot 3$ & 1.7 & 0 & $3(1-13)$ & $55(43 \cdot 3)^{\mathrm{a}}$ & 100 & 0 & 0 & $3(1-7)$ & $33(33 \cdot 0)^{\mathrm{a}}$ & 100 & 0 & 0 & $2(1-6)$ \\
\hline Dairy & $34(22 \cdot 4)^{\mathrm{a}}$ & $97 \cdot 1$ & $2 \cdot 9$ & 0 & $3(1-13)$ & $7(5 \cdot 5)^{\mathrm{b}}$ & $85 \cdot 7$ & $14 \cdot 3$ & 0 & $3(2-16)$ & $9(9 \cdot 0)^{\mathrm{b}}$ & 100 & 0 & 0 & $2(1-5)$ \\
\hline Sheep & $19(12 \cdot 5)^{\mathrm{a}}$ & $84 \cdot 2$ & $15 \cdot 8$ & 0 & $6(1-20)$ & $7(5 \cdot 5)^{\mathrm{a}}$ & $71 \cdot 4$ & $28 \cdot 6$ & 0 & $7(1-11)$ & $44(44 \cdot 0)^{\mathrm{b}}$ & $79 \cdot 5$ & $20 \cdot 5$ & 0 & $6(1-15)$ \\
\hline
\end{tabular}

*Malipati: porous interface; Chomupani: non-interface [site far away from the boundary of the park (GNP)]; Chizvirizviri: non-porous interface [an intact fence separating site from game park (Malilangwe)].

${ }^{\dagger}$ Figures with a different superscript in the same row under total owning are significantly different at $P<0.05$. 
Table 3. Summary of responses to issues on husbandry practices, role of wildlife in disease transmission and disease prevention methods by cattle and small ruminant keepers

\begin{tabular}{|c|c|c|c|c|c|c|c|c|c|}
\hline \multirow[b]{3}{*}{ Variables } & \multirow[b]{3}{*}{ Responses } & \multicolumn{6}{|c|}{ Site* } & & \\
\hline & & \multicolumn{2}{|c|}{ Malipati $(n=140)$} & \multicolumn{2}{|c|}{ Chomupani $(n=114)$} & \multicolumn{2}{|c|}{ Chizvirizviri $(n=69)$} & \multicolumn{2}{|c|}{ Overall $(n=323)$} \\
\hline & & No. & $\%(95 \% \mathrm{CI})$ & No. & $\%(95 \% \mathrm{CI})$ & No. & $\%(95 \% \mathrm{CI})$ & No. & $\%(95 \% \mathrm{CI})$ \\
\hline \multicolumn{10}{|l|}{ Extensive open grazing } \\
\hline During wet season & Yes & 137 & $97 \cdot 9^{\mathrm{a}}(93 \cdot 4-99 \cdot 4)$ & 111 & $97 \cdot 4^{\mathrm{a}}(91 \cdot 9-99 \cdot 3)$ & 64 & $92 \cdot 8^{\mathrm{a}}(83 \cdot 2-97 \cdot 3)$ & 312 & $96 \cdot 6(93 \cdot 8-98 \cdot 2)$ \\
\hline During dry season & Yes & 132 & $94 \cdot 3^{\mathrm{a}}(88 \cdot 7-97 \cdot 3)$ & 94 & $82 \cdot 5^{\mathrm{b}}(74 \cdot 0-88 \cdot 7)$ & 52 & $75 \cdot 4^{\mathrm{c}}(63 \cdot 3-84 \cdot 6)$ & 278 & $86 \cdot 1(81 \cdot 7-89 \cdot 6)$ \\
\hline Paddock grazing & Yes & 0 & $0 \cdot 0^{\mathrm{a}}(0 \cdot 0-0 \cdot 0)$ & 29 & $25 \cdot 4^{\mathrm{b}}(18 \cdot 0-34 \cdot 6)$ & 0 & $0 \cdot 0^{\mathrm{a}}(0 \cdot 0-0 \cdot 0)$ & 29 & $9 \cdot 0(6 \cdot 2-12 \cdot 8)$ \\
\hline Dry season supplementation & Yes & 55 & $39 \cdot 3^{\mathrm{a}}(31 \cdot 3-47 \cdot 9)$ & 56 & $49 \cdot 1^{\mathrm{a}}(39 \cdot 7-58 \cdot 6)$ & 56 & $81 \cdot 2^{\mathrm{b}}(69 \cdot 6-89 \cdot 2)$ & 167 & $51 \cdot 7(46 \cdot 1-57 \cdot 3)$ \\
\hline \multicolumn{10}{|l|}{ Water source during wet season } \\
\hline Dams & Yes & 25 & $17 \cdot 9^{\mathrm{a}}(12 \cdot 1-25 \cdot 4)$ & 102 & $89 \cdot 5^{\mathrm{b}}(82 \cdot 0-94 \cdot 2)$ & 41 & $59 \cdot 4^{\mathrm{c}}(46 \cdot 9-70 \cdot 9)$ & 168 & $52 \cdot 0(46 \cdot 4-57 \cdot 6)$ \\
\hline Rivers & Yes & 94 & $67 \cdot 1^{\mathrm{a}}(58 \cdot 6-74 \cdot 7)$ & 12 & $10 \cdot 5^{\mathrm{b}}(5 \cdot 8-18 \cdot 0)$ & 18 & $26 \cdot 1^{\mathrm{c}}(16 \cdot 6-38 \cdot 3)$ & 124 & $38 \cdot 4(33 \cdot 1-44 \cdot 0)$ \\
\hline Boreholes & Yes & 5 & $3 \cdot 6^{\mathrm{a}}(1 \cdot 3-8 \cdot 6)$ & 4 & $3 \cdot 5^{\mathrm{a}}(1 \cdot 1-9 \cdot 3)$ & 2 & $2 \cdot 9^{\mathrm{a}}(0 \cdot 5-11 \cdot 0)$ & 11 & $3 \cdot 4(1 \cdot 8-6 \cdot 2)$ \\
\hline Wells & Yes & 8 & $5 \cdot 7^{\mathrm{a}}(2 \cdot 7-11 \cdot 3)$ & 7 & $6 \cdot 1^{\mathrm{a}}(2 \cdot 7-12 \cdot 7)$ & 5 & $7 \cdot 3^{\mathrm{a}}(2 \cdot 7-16 \cdot 8)$ & 20 & $6 \cdot 2(3 \cdot 9-9 \cdot 6)$ \\
\hline \multicolumn{10}{|l|}{ Water source during dry season } \\
\hline Dams & Yes & 12 & $8 \cdot 6^{\mathrm{a}}(4 \cdot 7-14 \cdot 8)$ & 7 & $6 \cdot 1^{\mathrm{a}}(2 \cdot 7-12 \cdot 7)$ & 4 & $5 \cdot 8^{\mathrm{a}}(1 \cdot 9-14 \cdot 9)$ & 23 & $7 \cdot 1(4 \cdot 7-10 \cdot 6)$ \\
\hline Rivers & Yes & 58 & $41 \cdot 1^{\mathrm{a}}(33 \cdot 3-50 \cdot 1)$ & 17 & $14 \cdot 9^{\mathrm{b}}(9 \cdot 2-23 \cdot 1)$ & 25 & $36 \cdot 2^{\mathrm{a}}(25 \cdot 3-48 \cdot 8)$ & 100 & $31 \cdot 0(26 \cdot 0-36 \cdot 4)$ \\
\hline Boreholes & Yes & 40 & $28 \cdot 6^{\mathrm{a}}(21 \cdot 4-36 \cdot 9)$ & 30 & $26 \cdot 3^{\mathrm{a}}(18 \cdot 7-35 \cdot 5)$ & 26 & $37 \cdot 7^{\mathrm{a}}(26 \cdot 5-50 \cdot 2)$ & 96 & $29 \cdot 7(24 \cdot 9-35 \cdot 1)$ \\
\hline Wells & Yes & 45 & $32 \cdot 1(24 \cdot 7-40 \cdot 6)$ & 35 & $30 \cdot 7^{\mathrm{a}}(22 \cdot 6-40.1)$ & 24 & $34 \cdot 8^{\mathrm{a}}(24 \cdot 0-47 \cdot 3)$ & 104 & $32 \cdot 2(27 \cdot 2-37 \cdot 6)$ \\
\hline Contact with wildlife & Yes & 107 & $76 \cdot 4^{\mathrm{a}}(68 \cdot 4-83 \cdot 0)$ & 28 & $24 \cdot 6^{\mathrm{b}}(17 \cdot 2-33 \cdot 7)$ & 0 & $0 \cdot 0^{\mathrm{c}}(0 \cdot 0-0 \cdot 0)$ & 135 & $41 \cdot 8(36 \cdot 4-47 \cdot 4)$ \\
\hline Face challenges in livestock production & Yes & 136 & $97 \cdot 1^{\mathrm{a}}(92 \cdot 4-99 \cdot 1)$ & 92 & $80 \cdot 7^{\mathrm{b}}(72 \cdot 0-87 \cdot 3)$ & 59 & $85 \cdot 5^{\mathrm{b}}(74 \cdot 5-92 \cdot 5)$ & 287 & $88 \cdot 9(84 \cdot 8-92 \cdot 0)$ \\
\hline Disease transmission from wildlife & Yes & 128 & $91 \cdot 4^{\mathrm{a}}(85 \cdot 2-95 \cdot 3)$ & 41 & $36 \cdot 0^{\mathrm{b}}(27 \cdot 3-45 \cdot 6)$ & 45 & $65 \cdot 2^{\mathrm{c}}(52 \cdot 7-76 \cdot 0)$ & 214 & $66 \cdot 3(60 \cdot 8-71 \cdot 3)$ \\
\hline \multicolumn{10}{|l|}{ Disease prevention methods } \\
\hline Avoiding contact with wildlife & Yes & 31 & $22 \cdot 1^{\mathrm{a}}(15 \cdot 8-30 \cdot 1)$ & 12 & $10 \cdot 5^{\mathrm{b}}(5 \cdot 8-18 \cdot 0)$ & 17 & $24 \cdot 6^{\mathrm{a}}(15 \cdot 4-36 \cdot 7)$ & 60 & $18 \cdot 6(14 \cdot 6-23 \cdot 3)$ \\
\hline Dipping & Yes & 27 & $19 \cdot 3^{\mathrm{a}}(13 \cdot 3-27 \cdot 0)$ & 20 & $17 \cdot 5^{\mathrm{a}}(11 \cdot 3-26 \cdot 0)$ & 10 & $14 \cdot 5^{\mathrm{a}}(7 \cdot 5-25 \cdot 5)$ & 57 & $17 \cdot 7(13 \cdot 7-22 \cdot 3)$ \\
\hline Vaccination & Yes & 24 & $17 \cdot 1^{\mathrm{a}}(11 \cdot 5-24 \cdot 6)$ & 18 & $15 \cdot 8^{\mathrm{a}}(9 \cdot 9-24 \cdot 1)$ & 11 & $15 \cdot 9^{a}(8 \cdot 6-27 \cdot 2)$ & 53 & $16 \cdot 4(12 \cdot 6-21 \cdot 0)$ \\
\hline
\end{tabular}

*Figures with a different superscript in the same row are significantly different at $P<0.05$. 
higher percentage and none were from Chizvirizviri (non-porous interface). The majority (88.9\%) of farmers indicated that they face challenges in livestock production and Malipati had a significantly $(P<0.05)$ higher percentage of farmers facing livestock production challenges. Disease transmission from wildlife $(66 \cdot 3 \%, 214 / 323)$ was the most cited challenge with a significantly $(P<0 \cdot 01)$ higher percentage of the farmers mentioning disease transmission being from Malipati (porous interface). Buffaloes (S. caffer) $(47 \cdot 1 \%, 152 / 323)$ were indicated as playing an important role in the transmission of infections to livestock and other wild animals mentioned included the wildebeest (Connochaetes taurinus), kudu (Tragelaphus strepsiceros), eland (Taurotragus oryx), impala ( $A$. melampus), zebra (Equu sburchelli), bush pig (Potamochoerus larvatus) and jackals: both the side striped (Canis adustus) and black-backed (Canis mesomelas). Farmers cited avoiding contact with wildlife (18.6\%), dipping $(17 \cdot 7 \%)$ and vaccination $(16 \cdot 4 \%)$ as livestock disease preventive methods.

\section{Household level prevalence of abortion history}

Table 4 gives a summary of cattle and small ruminant keepers' responses to issues related to abortions. Overall, $54 \cdot 2 \%$ of them reported abortions in their herds in the last 5 years. However, a lower percentage $(27 \cdot 2 \%)$ knew about long calving intervals as an indicator of infertility of their cows. Knowledge on the causes $(17 \cdot 3 \%)$, spread $(8 \cdot 7 \%)$ and preventive methods $(13.3 \%)$ of abortions was very low among the farmers and investigations are rarely done $(12 \cdot 4 \%)$. A relatively low percentage $(24 \cdot 2 \%)$ of the farmers indicated that they burn and/or bury aborted foetuses and $22.3 \%$ would dispose them to dogs with the highest being from the porous area, Malipati (36.4\%). The remainder of the farmers just left the aborted foetuses to decompose in the open grazing areas where calving would have occurred. Overall, more than half $(56 \%)$ of the farmers indicated that wildlife plays a role in the cause of abortions with a significantly $(P<0 \cdot 05)$ higher percentage $(66.4 \%)$ of farmers from the porous area (Malipati) citing wildlife as a risk compared with those from non-porous interface and non-interface sites.

\section{Multivariable logistic regression analysis}

The multivariable logistic regression model revealed area of origin and the total number of cattle kept per household $(0=\leqslant 8 ; 1=>8)$ to be independently associated with the reported abortions in cattle herds in the previous 5 years (Table 5). The practice of keeping cattle together with sheep and/or goats was not associated with reported abortions. Respondents from Chizvirizvi and Malipati (interface areas) were approximately twice (odds ratio (OR) of $2 \cdot 2$ and $1 \cdot 9$, respectively) more likely to report abortions in their cattle herds compared with those from Chomupani (non-interface). Similarly, the odds of reporting abortions were higher $(\mathrm{OR}=2 \cdot 6 ; 95 \%$ confidence interval $(\mathrm{CI}) 1 \cdot 5-4 \cdot 3)$ in respondents from households keeping more than eight head of cattle compared with those keeping less than eight animals (Table 5). Significant interactions between variables were not detected. The Hosmer-Lemeshow goodness-of-fit test showed that the model fit the data $\left(\chi^{2}=3 \cdot 2\right.$, D.F. $\left.4, P=0.53\right)$ and predictive ability was fair (area under the ROC curve $=0 \cdot 64$ ).

\section{Expressed knowledge of zoonoses and risk factors}

A relatively higher percentage $(25 \cdot 4 \%)$ of cattle and small ruminants' keepers knew brucellosis as a cause of abortions compared with RVF $(11.5 \%)$ and leptospirosis $(4 \cdot 3 \%)$. Less than $20 \%$ of them knew at least one method of protecting themselves against zoonoses.

Overall, milk consumption by the respondents was very high $(87 \cdot 9 \%, 333 / 379)$ with $65 \cdot 8 \%$ of them indicating that they consume raw milk (Table 6). However, the practice of boiling milk was done by $<50 \%$ of the farmers $(46 \cdot 3 \%)$ and all those boiling were doing it for aesthetic reasons rather than to inactivate possible infectious agents. Most respondents (92.2\%) indicated that they obtain milk from their own animals and/or from their neighbours (Table 6). None of the respondents reported knowledge of known human infections by any of the three zoonotic diseases and as such, there were no preventative measures known.

\section{Focus group discussions}

All the three FGD mentioned contact with wildlife as a major risk factor for abortion in their cattle. However, farmers never reported any one infectious cause of abortion when further asked to name diseases that are transmitted from wildlife to livestock with possible effects on abortion. 'Brucellosis' was more familiar to communities than 'contagious abortion' but a number of participants thought the act of abortion was referred to as contagious abortion regardless of the cause. Use of 'half bulls' (bulls that have one testis erroneously left intact at castration) was often 
Table 4. Summary of responses to major issues on abortions by cattle and small ruminant keepers

\begin{tabular}{|c|c|c|c|c|c|c|c|c|c|}
\hline \multirow[b]{3}{*}{ Variables } & \multirow[b]{3}{*}{ Responses } & \multicolumn{6}{|c|}{ Site* } & & \\
\hline & & \multicolumn{2}{|c|}{ Malipati $(n=140)$} & \multicolumn{2}{|c|}{ Chomupani $(n=114)$} & \multicolumn{2}{|c|}{ Chizvirizviri $(n=69)$} & \multicolumn{2}{|c|}{ Overall $(n=323)$} \\
\hline & & No. & $\%(95 \% \mathrm{CI})$ & No. & $\%(95 \% \mathrm{CI})$ & No. & $\%(95 \% \mathrm{CI})$ & No. & $\%(95 \% \mathrm{CI})$ \\
\hline Abortions occurring in last 5 years & Yes & 79 & $56 \cdot 4^{\mathrm{a}}(47 \cdot 8-64 \cdot 7)$ & 50 & $43 \cdot 9^{\mathrm{b}}(34 \cdot 7-53 \cdot 5)$ & 46 & $66 \cdot 7^{\mathrm{a}}(54 \cdot 2-77 \cdot 3)$ & 175 & $54 \cdot 2(48 \cdot 6-59 \cdot 7)$ \\
\hline Know causes of abortions & Yes & 19 & $13 \cdot 6^{\mathrm{a}}(8 \cdot 6-20 \cdot 6)$ & 11 & $9 \cdot 7^{\mathrm{a}}(5 \cdot 2-17 \cdot 0)$ & 26 & $37 \cdot 7^{\mathrm{b}}(26 \cdot 5-50 \cdot 2)$ & 56 & $17 \cdot 3(13 \cdot 5-22 \cdot 0)$ \\
\hline Know how abortions are spread & Yes & 5 & $3 \cdot 6^{\mathrm{a}}(1 \cdot 3-8 \cdot 6)$ & 3 & $2 \cdot 6^{\mathrm{a}}(0 \cdot 7-8 \cdot 1)$ & 20 & $29 \cdot 0^{\mathrm{b}}(19 \cdot 0-41 \cdot 3)$ & 28 & $8 \cdot 7(5 \cdot 9-12 \cdot 4)$ \\
\hline Abortion investigations are done & Yes & 14 & $10 \cdot 0^{\mathrm{a}}(5 \cdot 8-16 \cdot 5)$ & 1 & $0 \cdot 9^{\mathrm{b}}(0 \cdot 1-5 \cdot 5)$ & 25 & $36 \cdot 2^{\mathrm{c}}(25 \cdot 3-48 \cdot 8)$ & 40 & $12 \cdot 4(9 \cdot 1-16 \cdot 6)$ \\
\hline Know at least one abortion preventive method & Yes & 21 & $15 \cdot 0^{\mathrm{a}}(9 \cdot 7-22 \cdot 3)$ & 3 & $2 \cdot 6^{\mathrm{b}}(0 \cdot 7-8 \cdot 1)$ & 19 & $27 \cdot 5^{\mathrm{c}}(17 \cdot 8-39 \cdot 8)$ & 43 & $13 \cdot 3(9 \cdot 9-17 \cdot 6)$ \\
\hline \multirow[t]{2}{*}{ Disposal of aborted foetus } & Burn or bury & 26 & $18 \cdot 6^{\mathrm{a}}(12 \cdot 7-26 \cdot 2)$ & 12 & $10 \cdot 5^{\mathrm{a}}(5 \cdot 8-18 \cdot 0)$ & 40 & $58 \cdot 0^{\mathrm{b}}(45 \cdot 5-69 \cdot 6)$ & 78 & $24 \cdot 2(19 \cdot 7-29 \cdot 3)$ \\
\hline & Dispose to dogs & 51 & $36 \cdot 4^{\mathrm{a}}(28 \cdot 6-45 \cdot 0)$ & 19 & $16 \cdot 7^{\mathrm{b}}(10 \cdot 6-25 \cdot 1)$ & 2 & $2 \cdot 9^{\mathrm{c}}(0 \cdot 5-11 \cdot 0)$ & 72 & $22 \cdot 3(18 \cdot 0-27 \cdot 3)$ \\
\hline Wildlife plays role in abortions & Yes & 93 & $66 \cdot 4^{\mathrm{a}}(57 \cdot 9-74 \cdot 1)$ & 50 & $43 \cdot 9^{\mathrm{b}}(34 \cdot 7-53 \cdot 5)$ & 38 & $55 \cdot 1^{\mathrm{c}}(42 \cdot 7-66 \cdot 9)$ & 181 & $56 \cdot 0(50 \cdot 4-61 \cdot 5)$ \\
\hline Know brucellosis as a cause of abortion & Yes & 28 & $20 \cdot 0^{\mathrm{a}}(13 \cdot 9-27 \cdot 8)$ & 17 & $14 \cdot 9^{\mathrm{a}}(9 \cdot 2-23 \cdot 1)$ & 37 & $53 \cdot 6^{\mathrm{b}}(41 \cdot 3-65 \cdot 6)$ & 82 & $25 \cdot 4(20 \cdot 8-30 \cdot 6)$ \\
\hline Know Rift Valley Fever as a cause of abortion & Yes & 13 & $9 \cdot 3^{\mathrm{a}}(5 \cdot 2-15 \cdot 7)$ & 16 & $14 \cdot 0^{a}(8 \cdot 5-22 \cdot 1)$ & 8 & $11 \cdot 6^{\mathrm{a}}(5 \cdot 5-22 \cdot 1)$ & 37 & $11 \cdot 5(8 \cdot 3-15 \cdot 6)$ \\
\hline Know leptospirosis as a cause of abortion & Yes & 6 & $4 \cdot 3^{\mathrm{a}}(1 \cdot 8-9 \cdot 5)$ & 7 & $6 \cdot 1^{\mathrm{a}}(2 \cdot 7-12 \cdot 7)$ & 1 & $1 \cdot 5^{\mathrm{a}}(0 \cdot 1-8 \cdot 9)$ & 14 & $4 \cdot 3(2 \cdot 5-7 \cdot 3)$ \\
\hline Know at least one zoonoses protection method & Yes & 43 & $30 \cdot 7^{\mathrm{a}}(23 \cdot 4-39 \cdot 2)$ & 5 & $4 \cdot 4^{\mathrm{b}}(1 \cdot 6-10 \cdot 4)$ & 3 & $4 \cdot 4^{\mathrm{b}}(1 \cdot 1-13 \cdot 0)$ & 51 & $15 \cdot 8(12 \cdot 1-20 \cdot 3)$ \\
\hline Cows have long calving intervals & Yes & 51 & $36 \cdot 4^{\mathrm{a}}(28 \cdot 6-45 \cdot 0)$ & 21 & $18 \cdot 4^{\mathrm{b}}(12 \cdot 0-27 \cdot 0)$ & 16 & $23 \cdot 2^{\mathrm{b}}(14 \cdot 2-35 \cdot 2)$ & 88 & $27 \cdot 2(22 \cdot 5-32 \cdot 5)$ \\
\hline
\end{tabular}

*Figures with a different superscript in the same row are significantly different at $P<0 \cdot 05$. 
Table 5. The Final multivariable logistic regression of the explanatory variables associated with reported abortions in cattle from Chomupani (non-interface), Chizvirizvi (non-porous interface) and Malipati (porous interface) areas in Chiredzi, Zimbabwe (2010-2015)

\begin{tabular}{|c|c|c|c|c|c|c|}
\hline \multirow[b]{2}{*}{ Variable } & \multirow[b]{2}{*}{ Level } & \multicolumn{5}{|c|}{ Multivariable Logistic Regression* ${ }^{*} \dagger$} \\
\hline & & $b$ & S.E. $(b)$ & $P$ & OR & $95 \% \mathrm{CI}$ \\
\hline & Constant & $-0 \cdot 8$ & $0 \cdot 3$ & 0.002 & - & - \\
\hline \multirow[t]{3}{*}{ Area } & Chomupani & - & - & - & - & - \\
\hline & Chizvirizvi & $0 \cdot 8$ & $0 \cdot 4$ & 0.03 & $2 \cdot 2$ & $1 \cdot 1-4 \cdot 3$ \\
\hline & Malipati & $0 \cdot 6$ & $0 \cdot 3$ & $0 \cdot 04$ & 1.9 & $1 \cdot 0-3 \cdot 5$ \\
\hline \multirow[t]{2}{*}{ Cattle/household } & $\leqslant 8$ head & - & - & - & - & - \\
\hline & $>8$ head & $0 \cdot 9$ & $0 \cdot 3$ & 0.000 & $2 \cdot 6$ & $1 \cdot 5-4 \cdot 3$ \\
\hline
\end{tabular}

$b$, logistic regression coefficient; S.E. $(b)$, standard error for the logistic regression coefficient; $P$, probability value; OR, odds ratio; CI, confidence interval.

* Overall data of the model: $\log$ likelihood $=-166 \cdot 8, \mathrm{LR} \chi^{2}(3$ D.F. $)=18 \cdot 3, P=0 \cdot 0004$, number of observations $=254$.

$\dagger$ Dependent variable: respondent reported abortion in the household cattle herd $(0=$ no, $1=$ yes $)$.

Table 6. Summary of responses to risky practices for contracting zoonoses by the respondents

\begin{tabular}{|c|c|c|c|c|c|c|c|c|}
\hline \multirow[b]{2}{*}{ Responses } & \multicolumn{2}{|c|}{ Malipati $(n=152)$} & \multicolumn{2}{|c|}{ Chomupani $(n=127)$} & \multicolumn{2}{|c|}{ Chizvirizviri $(n=100)$} & \multicolumn{2}{|c|}{ Overall $(n=379)$} \\
\hline & No. & $\%(95 \% \mathrm{CI})$ & No. & $\%(95 \% \mathrm{CI})$ & No. & $\%(95 \% \mathrm{CI})$ & No. & $\%(95 \% \mathrm{CI})$ \\
\hline Consume milk & 133 & $87 \cdot 5(80 \cdot 9-92 \cdot 1)$ & 113 & $89 \cdot 0(81 \cdot 9-93 \cdot 6)$ & 87 & $87 \cdot 0(78 \cdot 4-92 \cdot 6)$ & 333 & $87 \cdot 9(84 \cdot 0-90 \cdot 9)$ \\
\hline Consume raw milk* & 101 & $75 \cdot 9(67 \cdot 6-82 \cdot 7)$ & 65 & $57 \cdot 5(47 \cdot 9-66 \cdot 7)$ & 53 & $60 \cdot 9(49 \cdot 8-71 \cdot 0)$ & 219 & $65 \cdot 8(60 \cdot 4-70 \cdot 8)$ \\
\hline Boil milk* & 87 & $65 \cdot 4(56 \cdot 6-73 \cdot 3)$ & 49 & $43 \cdot 4(34 \cdot 2-53 \cdot 0)$ & 18 & $20 \cdot 7(13 \cdot 0-31 \cdot 0)$ & 154 & $46 \cdot 3(40 \cdot 8-51 \cdot 8)$ \\
\hline \multicolumn{9}{|l|}{ Source of milk } \\
\hline Own animals* & 100 & $75 \cdot 2(66 \cdot 8-82 \cdot 1)$ & 91 & $80 \cdot 5(71 \cdot 8-87 \cdot 1)$ & 66 & $75 \cdot 9(65 \cdot 3-84 \cdot 1)$ & 257 & $77 \cdot 2(72 \cdot 2-81 \cdot 5)$ \\
\hline Neighbours* & 27 & $20 \cdot 3(14 \cdot 0-28 \cdot 3)$ & 12 & $10 \cdot 6(5 \cdot 9-18 \cdot 2)$ & 11 & $12.6(6.8-21.9)$ & 50 & $15 \cdot 0(11 \cdot 5-19 \cdot 4)$ \\
\hline Others* & 6 & $4 \cdot 5(1 \cdot 9-10 \cdot 0)$ & 10 & $8 \cdot 9(4 \cdot 6-16 \cdot 1)$ & 10 & $11 \cdot 5(6 \cdot 0-20 \cdot 6)$ & 26 & $7 \cdot 8(5 \cdot 3-11 \cdot 4)$ \\
\hline
\end{tabular}

* The percentages are based on those consuming milk (133 for Malipati, 113 for Chomupani, 87 for Chizvirizviri \& 333 for Overall).

mentioned as a major risk factor of cattle abortion. Other cattle abortion causes mentioned included exertion due to overuse as draught power, witchcraft and some superstitions such as being herded by women who are experiencing their menses.

The zoonotic significance of the causes of abortions in livestock was largely unappreciated with inappropriate handling of aborted foetuses and placentae reported. In fact, all the group discussions revealed that some elderly people consume meat from aborted foetuses and that consumption of raw milk is quite prevalent with those that boil milk doing it for aesthetic reasons rather than prevention of human infection by milk-borne pathogens such as brucellosis.

\section{Key informant responses}

The key informants interviewed consisted of the Department of Parks and Wildlife Management
Authority, GNP, The Malilangwe Wildlife Conservancy Trust officials, the staff at the Department of Field Veterinary Services at each study area and the Ministry of Health and Child Care officials at the local clinic at each study site.

\section{DEPARTMENT OF PARKS AND WILDLIFE MANAGEMENT AUTHORITY, GNP}

This group was made up of the area manager, the ecologist and three rangers. It emerged during the discussions that the livestock at the porous interface was often grazed in the national park especially during the dry season when pastures were poor in the communities. Wildlife often strayed into communities particularly during the wet season when agricultural crops were abundant. Because of low average annual rainfall in the areas, the Mwenezi River was usually the 
major water source for both wildlife and livestock. Wildlife/livestock interaction was therefore high with high incidences of disease sharing, predation and poaching heightening the conflict between the national parks and adjacent communities. The group however had no evidence of abortions in wildlife as aborted fetuses would immediately be consumed by carnivores. They attributed the dwindling numbers of wildlife species to poaching rather than decreased reproduction. They were clearly aware of brucellosis in wildlife and its zoonotic importance but only from feedback meeting with previous researchers. Both Leptospirosis and RVF were largely unknown.

\section{THE MALILANGWE WILDLIFE CONSERVANCY TRUST}

Interviewed as a group, the key informants included the general manager, two ecologists and two rangers. The group reported no straying of livestock into the conservancy as the security fence was quite intact. They knew of Brucellosis, Leptospirosis and RVF both as agents of abortion and zoonoses. However, no reports of such diseases had been recorded in the conservancy in both wildlife and humans.

\section{DEPARTMENT OF LIVESTOCK AND VETERINARY SERVICES}

There is an animal health centre in each of the study areas manned by a veterinary extension officer and a livestock production officer and the two of them were interviewed at each interface area. Abortion in cattle was reported to be a problem in the area and in each case brucellosis was suspected as it was the major disease known to cause abortion. Their knowledge of the disease was mainly as a result of various researches that had been carried out in the areas. Leptospirosis and RVF were known as diseases of livestock, but their roles in abortion in cattle were not known. Since the role of the veterinary staff is mainly disease surveillance, samples for definitive diagnosis of abortions were often submitted to the Central Veterinary Laboratory, but results never came back to them as the laboratory did not have the capacity to run the tests due to underfunding. Although they reported knowing brucellosis as a zoonosis, the staff reported that there was little effort being put towards conscientising communities as the authorities tended to focus more on rabies and anthrax. They also reported a number of risk factors for human and livestock infection such as consumption of raw milk, consumption of undercooked food, open grazing systems and co-sharing of water sources between people, livestock and wildlife. They believed that wildlife had a role to play in transmission of these diseases to livestock.

\section{MINISTRY OF HEALTH AND CHILD CARE}

Health officials at three rural health centres covering each of the study sites were interviewed. The officials at each centre included the head nurse, two state registered nurses and one environmental health officer. The general view was that the centres were inadequately equipped for the diagnosis of zoonoses and would often treat cases of reported fever and flu-like symptoms as cases of malaria which is very prevalent in those areas. Cases that did not respond to malaria therapy would then be referred to Chiredzi District Hospital and results were never communicated to them. They also reported lack of inadequate campaigns to educate communities on zoonoses and how they can be prevented. Much of Government efforts are focused on rabies and to some extent anthrax. They were however aware of brucellosis, leptospirosis and RVF as important zoonoses.

\section{DISCUSSION}

The aim of this study was to investigate the awareness of zoonotic causes of abortion in cattle, including identification of factors that could predispose cattle and humans to infection in communities living at the human/livestock/wildlife interface areas of the Great Limpopo Transfrontier Conservation Area of Zimbabwe. Further, the study also compared the frequencies of reporting abortion in cattle at three selected interface types where contact with wildlife is either unrestricted (porous interface), restricted by fencing (non-porous interface) or totally absent (noninterface) with a view to determine if exposure of cattle to wildlife influences the frequency of reporting abortion by the farmers. The study established that most of the respondents underwent formal education of at least primary school making the level of education unlikely to impact negatively on the results of the questionnaires. However, translations of the questionnaires into the vernacular language used in the areas were done at each interview site whenever necessary. It is noteworthy that earlier studies conducted in areas 
demonstrated that cattle keepers living at the periphery of conservation areas in the country generally have a good knowledge about livestock-related issues [15].

There are several sources of bias in this study. Firstly, not all respondents owned cattle and therefore their knowledge of cattle abortion and zoonoses could be limited. However, all of them had owned cattle at some point and in fact some pointed to husbandry constraints and abortions as some of the reasons why they had no cattle at the time of the interviews. It can still be argued that the land tenure patterns in these communities allow common sharing of information between farmers regardless of livestock ownership. In addition, livestock and livestock products such as meat and milk are often communally shared such that the risk of human infection by livestock zoonoses may not significantly differ between those farmers that own livestock and those that do not. This is supported by our results, which indicate that some households that reported consuming milk indicated neighbours as their source of the milk. The second notable source of bias is the implication of wildlife as a source of infection for cattle abortions by respondents living in the porous interface. This can be attributable to already existing conflicts between livestock owners and wildlife due to known and much publicised diseases such as FMD. Lastly, not all abortions are infectious and even those that are infectious are not necessarily zoonotic. Our time frame of cattle abortions within the last 5 years can be a source of recall bias.

Results of the present study demonstrated the importance of livestock to rural farmers as evidenced by a high proportion of the respondents keeping livestock. Eighty to ninety perc ent of livestock population in Zimbabwe is in the smallholder farming areas [21] where livestock production is a major food security contributor to more than $75 \%$ of the population [22]. Despite a high livestock ownership proportion, livestock numbers per household in the study areas is low as evidenced by low median herd/ flock sizes and this agrees with earlier observations $[23,24]$. Livestock diseases, inadequate grazing and water, high drug costs, weak veterinary extension and theft are the most frequently reported livestock production constraints in these areas [25-27]. Livestock diseases occurrence was the most cited constraint particularly by those rural farmers at the porous interface area.

The main findings of this study is that cattle abortion is reported by the farmers in all the three study sites and more than $50 \%$ of the respondents indicated that it was experienced in their herds in the last 5 years. This agrees with other studies done previously in the same areas [7, 17] and in other areas in the country [28]. However, the causes of abortion are barely known despite the fact that these previous studies have demonstrated the presence of Brucella antibodies in cattle with a history of abortion. Such lack of knowledge can be partly attributable to inefficient feedback to communities by researchers on their findings. Abortions are rarely investigated and in cases where investigations are initiated, results are often inconclusive and seldom availed to the farmers due to limited diagnostic resources of the veterinary authority. This compromise in diagnostic efficiency particularly in developing countries due to insufficient infrastructure has been reported before [29, 30]. Therefore, the causes of abortion, their transmission modes and preventative actions are rarely known by the farmers, as proven by this study, because they are rarely investigated with the appropriate tools by the veterinary services. Furthermore, the zoonotic significance of these causes of abortion is not known to majority of farmers. Previous studies in Zimbabwe and neighbouring countries have also reported lack of knowledge on the zoonotic importance of some of the causes of abortion such as brucellosis, leptospirosis and $\mathrm{RVF}$ [31, 32]. However, knowledge of a disease is a crucial step in the development of prevention and control measures [33].

Despite the difficulties of identifying independent herds in smallholder farming systems as grazing and watering is often co-shared, households with large herd sizes were more at risk of having abortions. This is in agreement with the studies by Matope et al. [5], Megersa et al. [34] and Muma et al. [3] who all reported Brucella seroprevalence to increase with increasing herd size and stocking density. The same is true for leptospirosis [35]. Increasing herd sizes is often associated with concentration of pathogens and therefore high odds of transmission of infection within herds. In Zimbabwe, for example, brucellosis was at some point mainly confined to commercial farms where cattle are kept in large herds $[6$, 36]. The dichotomisation of herd size to investigate its effect on the odds of reporting abortion is a limitation that may result in loss of information and sometimes even inaccurate results [37].

Interface areas bordering the national park (Malipati, Chizvirizvi) were more likely to report abortions in their cattle. According to farmers, contact with wildlife occurs mainly during dry season 
grazing and at common water points as well as some wild carnivores that encroach into communities for livestock predation. Wildlife has been proven to be a reservoir of infection for a number of livestock diseases, such as FMD $[11,38]$. In fact, among the causes of abortion in livestock that have been demonstrated in wildlife are brucellosis in African buffalos ( $S$. caffer), and many other ungulate species such as eland (T. oryx), waterbuck (Kobusellipsi prymnus), and impala (A. melampus) $[9,38]$ and RVF in African buffalo (S. caffer), black rhino (Diceros bicornis), lesser kudu (T. strepsiceros), impala (A. melampus), African elephant (Loxodonta africana), waterbuck (K. prymnus), lion (Panthera leo), giraffe (G. camelopardalis), plains zebra (E. burchelli), wildebeest (Connochaete staurinus), eland ( $T$. oryx) and warthog (Phacochoerus africanus) [8, 39]. The majority of these wildlife species are resident in GNP and interact with livestock at porous interfaces making transmission possible. Brucellosis and leptospirosis are mainly shed in products of abortion and subsequent vaginal discharges and urine, which can contaminate both pastures and shared water sources. $\mathrm{RVF}$ on the other hand, is mainly arthropod borne and the mosquito vector responsible for its spread has been known to fly over long distances [40]. It should be noted that transmission of these diseases, especially brucellosis, between wildlife and livestock has never been fully proven $[17,41]$ and will be a major part of this broader investigation.

Our results do not suggest that households that own multiple livestock ruminant species are more likely to report abortions in their cattle herds. This is contrary to findings of other studies [3, 5, 34, 35]. While it can be appreciated from these previous studies that the presence of goats/sheep on the farm can result in pasture and water source contamination with potential causes of abortion, this effect is likely to be noticeable in commercial set ups where herds are kept closed from neighbouring herds. The open grazing system and communal dipping system reported by more than $95 \%$ of the respondents allow mixing of herds and interspecies grazing and therefore confounding the effects of multiple livestock species on individual households. Bulls are usually shared due to communal grazing resulting in high chances of uniformly spreading venereal infections causing abortion such as campylobacteriosis, trichomoniasis and to some extent leptospirosis across all herds.

In conclusion, cattle abortion is quite prevalent in the three interface areas as reported by the farmers.
Although the majority of farmers are not aware of the specific causes of abortions, most of them, particularly those at interface areas, perceive contact of their cattle with wildlife to play a role in abortion occurrence. This study identified porous interface areas and increased household cattle herd sizes to be independently associated with increased reporting of abortion by farmers. However, other risk practices identified by this study include poor disposal of cattle abortion products, lack of sufficient knowledge of causes and prevention of cattle abortion, use of communal bulls and open access grazing and water sources. Consumption of raw milk, improper handling of abortion products and handling and consuming contaminated meat are the major risky practices that can predispose humans to infection with brucellosis, leptospirosis and RVF. More research is required to detect the causes of abortion in these areas and advise the farmers on how to protect their livestock and themselves as most causes of abortion are zoonotic.

\section{SUPPLEMENTARY MATERIAL}

The supplementary material for this article can be found at https://doi.org/10.1017/S0950268817000097.

\section{ACKNOWLEDGEMENTS}

We thank the Ministère Français des Affaires Etrangères for supporting Masimba Ndengu's research through the FSP-RenCaRe project (FSP no 2011/36). This work was conducted within the framework of the Research Platform 'Production and Conservation in Partnership' (http://www.rp-pcp. org). We thank the farmers from Malipati, Chomupani and Chizvirizvi, and the staff of the Veterinary Services and National Parks and Wildlife Management Authority (Gonarezhou NP) for their collaboration.

\section{DECLARATION OF INTEREST}

None.

\section{REFERENCES}

1. Zishiri S. Livestock Ownership, Access and Management by Small-Scale Communities: An Attempt to Understand Opportunities and Constraints to Institutionalisation of Locally Based Disease and Quality Control by Herders in the Sengwe Communal 
Land, Zimbabwe (MSc thesis). Centre for Applied Social Sciences, University of Zimbabwe, Harare, 2012.

2. Bengis RG, Kock RA, Fischer J. Infectious animal diseases: the wildlife/livestock interface. Rev-Office of International Epizootics 2002; 21: 53-65.

3. Muma JB, et al. Risk factors for brucellosis in indigenous cattle reared in livestock-wildlife interface areas of Zambia. Preventive Veterinary Medicine 2007; 80: 306-317.

4. Madsen M. The current state of brucellosis in Zimbabwe. Zimbabwe Veterinary Journal 1989; 20: 133-149.

5. Matope G, et al. Herd-level factors for Brucella seropositivity in cattle reared in smallholder dairy farms of Zimbabwe. Preventive Veterinary Medicine 2010; 94: 213-221.

6. Swanepoel R, Blackburn NK, Lander KP. The occurrence, diagnosis and control of brucellosis in cattle in Rhodesia. Rhodesia Veterinary Journal 1976; 7: 24-31.

7. Gomo C, et al. Survey of brucellosis at the wildlife-livestock interface on the Zimbabwean side of the Great Limpopo Transfrontier Conservation Area. Tropical Animal Health and Production 2012; 44: 77-85.

8. Caron A, et al. Relationship between burden of infection in ungulate populations and wildlife/livestock interfaces. Epidemiology and Infection 2013; 141: 1522-1535.

9. Madsen M, Anderson EC. Serological survey of Zimbabwe wildlife for brucellosis. Journal of Zoo and Wildlife Medicine 1995; 26: 240-245.

10. Feresu SB. Serological survey of leptospiral antibodies in cattle in Zimbabwe. Tropical Animal Health and Production 1987; 19: 209-214.

11. Vosloo W, et al. The possible role that buffalo played in the recent outbreaks of foot-and-mouth disease in South Africa. Annals of the New York Academy of Sciences 2002; 969: 187-190.

12. Du Toit JT. Coexisting with cattle. Science 2011; 33: 1710-1711.

13. Lamarque F, et al. Human-Wildlife Conflict Causes Consequences and Management Strategies. Rome: FAO, 2009.

14. De Garine-Wichatitsky M, et al. Consequences of animals crossing the edges of transfrontier parks. In: Andersson J, Dzingira V, Cumming D, Giller K, eds. Transfrontier Conservation Areas People Living on the Edge. New York and London: Earthscan, 2013, pp. 137-162.

15. Cumming DHM. Sustaining Animal Health and Ecosystem Services in Large Landscapes - 2nd Draft. Wildlife Conservation Society, 2004 (http://www.wcsahead.org/workinggrps_limpopo.html).

16. Gandiwa E, Zisadza $\mathbf{P}$. Wildlife management in Gonarezhou National Park, Southeast Zimbabwe: climate change and implication for management. Nature \& Fauna 2010; 25: 101-110.

17. Gomo C, et al. Detection of Brucella abortus in Chiredzi district in Zimbabwe. Onderstepoort Journal of Veterinary Research 2012; 79. doi: 10.4102/ojvr.v79i1.417.

18. Chikerema SM, et al. Awareness and attitude towards zoonoses with particular reference to anthrax among cattle owners in selected rural communities of Zimbabwe. Vector-Borne and Zoonotic Diseases 2013; 13: 243-249. doi: 10.1089/vbz.2011.0916.

19. Rabiee F. Focus-group interview and data analysis. Proceedings of the Nutrition Society 2004; 63: 655-660.

20. Dohoo I, Martin W, Stryhn H. Veterinary Epidemiologic Research, AVC Inc.. Charlottetown: Prince Edward Island, 2003, pp. 27-407.

21. Njagu C. Overview of Small Holder Livestock Sector Division of Veterinary Field Services. The Department of Agriculture Coordination Working Group Journal. The Emergency Rehabilitation and Coordination Unit of the FAO in Zimbabwe, 2011, No. 62 (ftp://ftp.fao. org/TC/CPF/Countries/Zimbabwe/CPF_ZIM).

22. Agrisystems. National Livestock Development Study for Zimbabwe. Draft Main Report. Phase 1. Harare, Zimbabwe: Agrisystems Ltd and Pricewaterhouse Coopers, 2000.

23. Ngongoni NT, et al. Factors affecting milk production in the smallholder dairy sector of Zimbabwe. Livestock Research for Rural Development 2006; 18. (http://www.lrrd.org/lrrd18/5/ngon18072.htm).

24. Ndebele JJ, et al. Cattle breeding management practices in the Gwayi smallholder farming area of South-western Zimbabwe. Livestock Research for Rural Development 2007; 19. (http://www.lrrd.org/lrrd19/12/ndeb19183.htm).

25. Masama E, et al. Reproduction and lactation performance of cattle in a smallholder dairy system in Zimbabwe. Tropical Animal Health and Production 2003; 35: 117-129.

26. Mutibvu T, et al. Constraints and opportunities for increased livestock production in communal areas: a case study of Simbe, Zimbabwe. Livestock Research for Rural Developmen 2012; 24. (http://www.lrrd.org/ lrrd24/9/muti24165.htm).

27. Chatikobo $\mathbf{P}$, et al. Participatory diagnosis and prioritization of constraints to cattle production in some smallholder farming areas of Zimbabwe. Preventative Veterinary Medicine 2013; 109: 327-333.

28. Matope G, et al. Risk factors for Brucella spp. infection in smallholder household herds. Epidemiology and Infection. 2011; 139: 157-164.

29. Bharti AR, et al. Leptospirosis: a zoonotic disease of global importance. The Lancet 2003; 3: 757-771.

30. Esen S, et al. Impact of clinical and laboratory findings on prognosis in leptospirosis. Swiss Medical Weekly 2004; 134: 347-352.

31. Mosalagae D, Pfukenyi DM, Matope G. Milk producers' awareness of milk-borne zoonoses in selected smallholder and commercial dairy farms of Zimbabwe. Tropical Animal Health and Production 2011; 43: 733-739.

32. Ijale GO, Ajogi I, Dzikwi AA. Determination of risk factors and level of awareness of caprine brucellosis in Ojulga, Benue State, Nigeria. Bulletin of Animal Health and Production 2014; 62: 175-179.

33. Tschopp R, et al. Bovine tuberculosis and brucellosis prevalence in cattle from selected milk cooperatives in Arsi zone Oromia region, Ethiopia. Bio Medical Central Veterinary Research 2013; 9: 163. doi: 10.1186/1746-6148-9-163. 
34. Megersa B, et al. Cattle brucellosis in traditional livestock husbandry practice in Southern and Eastern Ethiopia, and its zoonotic implication. Acta Veterinaria Scandinavia 2011; 53: 24. Published online 2011 Apr 7. doi: 10.1186/1751-0147-53-24.

35. Schoonman L, Swai ES. Herd- and animal-level risk factors for bovine leptospirosis in Tanga region of Tanzania. Tropical Animal Health and Production 2010; 42: 1565-1572.

36. Mohan K, et al. Brucellosis surveillance and control in Zimbabwe: bacteriology and serological investigation in dairy herds. Onderstepoort Journal of Veterinary Research 1996; 63: 47-51.

37. Collins GS, et al. Quantifying the impact of different approaches for handling continuous predictors on the performance of a prognostic model. Statistics in Medicine 2016; 35: 4124-4135. doi: 10.1002/sim.6986.
38. Godfroid J. Brucellosis in wildlife. Scientific and Technical Review 2002; 21: 277-286. Medline: 11974615.

39. Miller M, et al. Sero-survey for selected viral agents in white rhinoceros (Ceratotherium simum) in Kruger National Park, 2007. Journal of Zoo and Wildlife Medicine 2011; 42: 29-32.

40. Daubney R, Hudson JR, Granham PC. Enzootic hepatitis or Rift Valley fever: an undescribed virus disease of sheep, cattle and man from East Africa. Journal of Pathology and Bacteriology 1931; 34: 545-579.

41. Kilpatrick AM, Gillin CM, Daszak P. Wildlifelivestock conflict: the risk of pathogen transmission from bison to cattle outside Yellowstone National Park. Journal of Applied Ecology 2009; 46: 476-485. 